\section{Ogólnopolska Konferencja Naukowa pt. „Zasoby wewnętrzne i rodzinne wychowanków młodzieżowych ośrodków socjoterapii w sieci wsparcia społecznego" (Warszawa, 4 marca 2016 r.)}

Forum Pedagogiczne $2016 / 1$

Wpłynęło: 20.05.2016 Zatwierdzono do druku: 20.05.2016

W dniu 4 marca 2016 r. na Wydziale Nauk Pedagogicznych Uniwersytetu Kardynała Stefana Wyszyńskiego odbyła się Ogólnopolska Konferencja Naukowa „Zasoby wewnętrzne i rodzinne wychowanków młodzieżowych ośrodków socjoterapii w sieci wsparcia społecznego".

Konferencję otworzyła prodziekan WNP UKSW Anna Fidelus, która powitała zaproszonych prelegentów, przedstawicieli Ośrodka Rozwoju Edukacji i Biura Rzecznika Praw Dziecka. Wśród zaproszonych gości znalazły się także osoby reprezentujące młodzieżowe ośrodki socjoterapii z Wrocławia, Żychlina, Goniądza, Lublina, Józefowa. Następnie prodziekan przedstawiła problematykę młodzieżowych ośrodków socjoterapii, prezentując swoje aktualne doświadczenia badawcze, realizowane w projekcie mającym na celu poznanie sytuacji wychowanków MOS-ów. Określiła podstawowe przyczyny trafiania do tych placówek. Przybliżyła trudności leżące zarówno po stronie rodziców, jak i szkoły w reagowaniu na problemy młodzieży, w efekcie prowadzące do przekazywania odpowiedzialności za wychowanie młodzieżowym ośrodkom socjoterapii. W wypowiedzi Anny Fidelus pojawiło się pytanie o motywy i intencje rodziców umieszczających dziecko w placówce. Podkreślono także zasadność istnienia ośrodków. Prelegentka zwróciła uwagę, że często środowisko nie jest przygotowane do przyjęcia dziecka powracającego z MOS-u. W podsumowaniu wypowiedzi pojawiła się też kwestia działalności inkluzyjnej, która powinna być podejmowana zarówno w wymiarze osobowym, jak i wspólnotowym.

Powyższe nawiązanie do słów Andrzeja Bałandynowicza (UW) pozwoliło zaprezentować pierwszego z zaproszonych prelegentów. Jego referat Socjoterapia jako powrót do ojczyzny duszy dziecka przybliżył kwestię pamięci jako wyznacznika godności osoby. Działanie na poziomie kultury polegające na „rozumieniu tych innych" potrzebuje określenia więzi, zrozumienia przez drugiego człowieka i pojawienia się osobowej relacji wychowanka z wychowawcą. Zdaniem prelegenta nie można mówić o wychowaniu bez kształtowania relacji emocjonalno-wolitywnej 
na płaszczyźnie szacunku prowadzącego do autonomii i odnajdywania swojej „ojczyzny duszy”.

Temat Przywracanie zaburzonej równowagi nieletnim $w$ procesie resocjalizacji inkluzyjnej zaprezentowała Anna Kieszkowska (UJK). W swoim wystąpieniu omówiła praktyczną stronę przywracania zaburzonej równowagi i powracania do pełnej autonomii u dzieci i młodzieży. W referacie poruszone zostały także temat zasad przyjmowanych podczas wyboru wartości oraz problem zdolności koniecznych, aby zaadaptować się do pełni życia i przyjąć wsparcie pochodzące $z$ relacji w rodzinie. Zwrócono także uwagę, że poszukiwanie własnej tożsamości przy boku wychowanka to istotny cel socjoterapii.

Następną prelegentką była Małgorzata Przybysz-Zaremba (WNR UKSW), która przedstawiła temat Rodzina jako "generator" zachowań problemowych młodzieży - wybrane aspekty diagnostyczne. Studium przypadku. Przybliżyła ona sytuację konkretnej rodziny, będącej przyczyną problemów w zachowaniu 13-letniej dziewczynki.

Kolejną osobą, która zabrała głos, był dyrektor Ośrodka Rozwoju Edukacji Sławomir Kuligowski. Uczestnicy konferencji mogli się zapoznać z ideą specjalistycznych punktów konsultacyjnych, których powstanie było odpowiedzią na problemy współczesnej szkoły, mogą z nich korzystać zarówno uczniowie, jak i rodzice oraz nauczyciele - w równym stopniu. Prelegent na przykładzie egzaminu gimnazjalnego przedstawił stan edukacji w Polsce i kwestię sukcesu edukacyjnego poszczególnych dzieci.

Pierwszą część konferencji zakończyła wypowiedź Barbary Galas (WNP UKSW): Dzieci anomii: kondycja moralna społeczeństwa polskiego a wychowanie. Zostały w niej przedstawione sytuacja ekonomiczna po transformacji ustrojowej i jej wpływ na powstawanie anomii jako stanu społeczeństwa i poczucia jednostki funkcjonującej w tym społeczeństwie.

Po przerwie miała miejsce dyskusja podsumowująca z udziałem pracowników MOS-ów. Wzięli w niej udział: Sławomir Moczydłowski (dyrektor Młodzieżowego Centrum Edukacji i Readaptacji Społecznej w Goniądzu), Anna Fidelus (UKSW), Andrzej Bałandynowicz (UW), Teresa Kaniowska (ORE), Ludwika Rutkowska, dyrektor Specjalnego Ośrodka Szkolno-Wychowawczego w Żyrardowie - Monika Modrzejewska.

Spotkanie pracowników naukowych, przedstawicieli placówek socjoterapii i innych oraz studentów było ubogacające. Szczególnie dla tych ostatnich, gdyż mogli zarówno pogłębić swoją wiedzę teoretyczną, jak i skorzystać z doświadczeń praktycznych. Dziękujemy za taką możliwość. 